\title{
建築用ゴム系材料の大気中のオゾンによる劣化の予測 \\ PREDICTION OF OZONE DEGRADATION OF RUBBER SHEETS FOR ROOFING MATERIALS, EXPOSED IN THE AIR
}

\author{
田中享二*, 宋 炳昌**, 小池迪夫*** \\ Kyoji TANAKA, Byung Chang SONG and Michio KOIKE
}

\begin{abstract}
The procedure to predict to time to crack initiation and rupture of rubber sheets by ozone is described. Five kinds of rubber sheets were exposed in the air for three years at Yokohama, measuring ozone concentration and temperature of the specimens every 10 minute. The time to the failure of each sheet was calculated by the proposed method, using both the measured data, and were compared" with the exposure test results. The predicted times approximately agreed with the test results, and the proposed method was considered to be applicable to estimate the ozone degradation of the rubber sheets exposed in the air.
\end{abstract}

Keywords : prediction, ozone degradation, rubber sheet, outdoor exposure, crack initiation, rupture 予測, オゾン劣化, ゴム系材料, 屋外暴露, 亀裂, 破断

\section{1.はじめに}

建築用ゴム系材料のオゾン劣化研究の最終目的は実際 に使用される環境下での劣化, すなわち, 大気環境下で の劣化を定量的に評価しようとする点に集約化される。 なぜならば，オゾン濃度が高いのは屋外であり，また， これら材料は屋外で使用されることが多いからである。 ところで, 従来のオゾン試験のほとんどは材料のオゾン に対する抵抗性能を知ることだけに主眼がおかれてお り，そのため特定温度・オゾン環境下での試験が一般的 であり, また，それで十分その目的を満足するものであっ た。しかし建築用材料としてこれらの材料を使用する際 には，漠然としたオゾンに対する性能というよりは，い つ頃欠陥が発生するか，あるいはいつ頃までの使用を期 待しうるか，という時間に関する情報が重要となる。そ のためには, 屋外でのオン゙ンによる劣化, 特に任意に変 動している環境下での劣化を定量的に評価する必要があ る。

前報”までで, その準備段階として, オゾン濃度と温 度が任意に変動する環境下での欠陥発生時間を, 劣化現 象の加算性を仮定した推定手法を用いて検討し，その有 効性について示した。しかし，これらではオゾン濃度は 変動しているものの, 比較的高濃度の室内実験としてな されたものであり，濃度も低くしかもより複雑に変動す る現実の環境下でなされたものではない。したがって,
現実の環境下でこの手法の有用性を示しておく必要があ る。

本研究はそのためオゾン濃度, 材料温度を継続して測 定しながら大気暴露試験を行い，その結果をもとに前報 までで示した考え方，予測手法の有効性について検討し たものである。

次に既往の研究についてであるが，従来からゴム系材． 料の耐久性を調べる目的で暴露試験はしばしば用いられ る方法であり，報告も多い。しかし，多くのものは材料 がどのように劣化するかという，記述を主とした実務的 なものであり，材料をよ゙のように評価してゆけば良いの かという観点からの研究は多くはない。この観点からの 研究としては大気中のオキシダント,オゾンの影響につ いて論じられた Antti Soininen ${ }^{2)}$, Haagen-Smit ${ }^{3)}$, $\mathrm{Vacca}^{4)}$ ，須賀 ${ }^{5)}$ 暴露試験がある。これらは一般工業用 ゴム系材料について行われたものであるが，建築用ゴム 系材料に焦点を合わせたものとして高木 ${ }^{6)}$, 藤木 ${ }^{7)}$, 加藤 ${ }^{81}$ らの研究があり, 特に後二者では本論文で取り扱おう之 しているオゾン試験との関連についても論及されてい る。しかし，いずれも特定期間経過した後の暴露試験結 果とオゾン試験結果の相関関係をもとにしており，特定 地域だけについて有効なものであり，一般性のあるもの ではない。時々刻々と変化する屋外環境条件を取り込み, オゾン劣化を評価しようとする試み（したがって環境条
* 東京工業大学 '助教授・工博

** 大韓住宅公社 研究員. 工博

*** 千葉工業大学 教授. 工博
Assoc. Prof., Tokyo Institute of Technology, Dr. Eng. Researcher, The Korea Housing Corporation, Dr. Eng. Prof., Chiba Institute of Technology, Dr. Eng. 
件さえ明らかであれば任意地点でのオゾン劣化を予測し うる)，は筆者らの知る範囲では皆無である。

\section{2. 大気暴露試験}

\section{1 大気暴露環境}

ここでの暴露試験は大気中のオゾンによる劣化のみを 対象としている。建築用ゴム系材料の亀裂発生には，才 ゾンのほかに紫外線も影響を及ばす9)。ここでは大気中 のオゾンによる劣化のみを対象としているため, 紫外線 の影響を除去し，オゾンのみが作用する環境を作り出す 必要がある。そのため, 写真一1に示すように，日射， 雨水等を遮断し空気の流通のみを可能とした, 周囲を ルーバーで取り囲んだ日陰空間を作成し，その中に試験 片を設置した。なお，試験期間中，空間内のオゾン濃度 および材料温度を 10 分間隔で継続測定した。

\section{2 試料および試験片}

試料は前報1ままでと同様，屋根防水用材料として用い

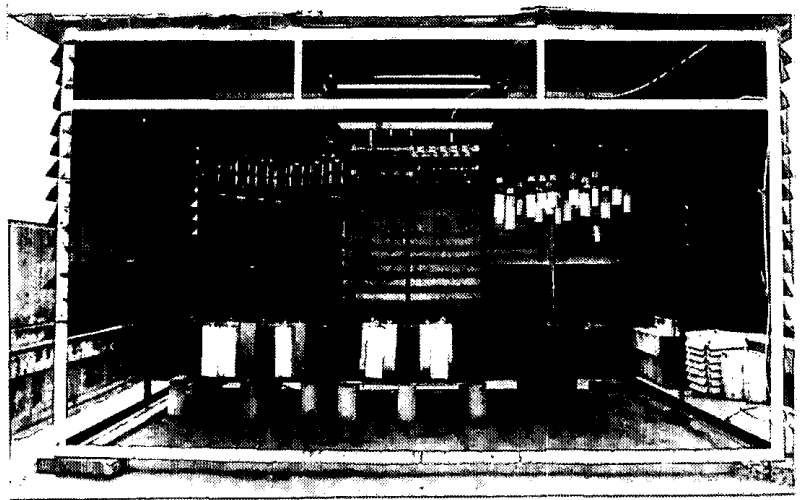

写真一1 日陰空間における暴露試験状況

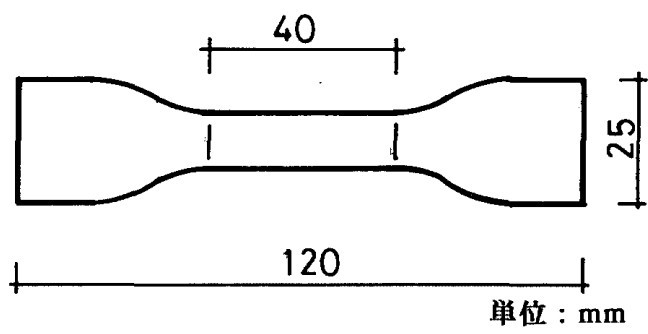

図一1 ダンベル状 1 号形試験片

表一1 試料の配合比，加硫度および基本物性

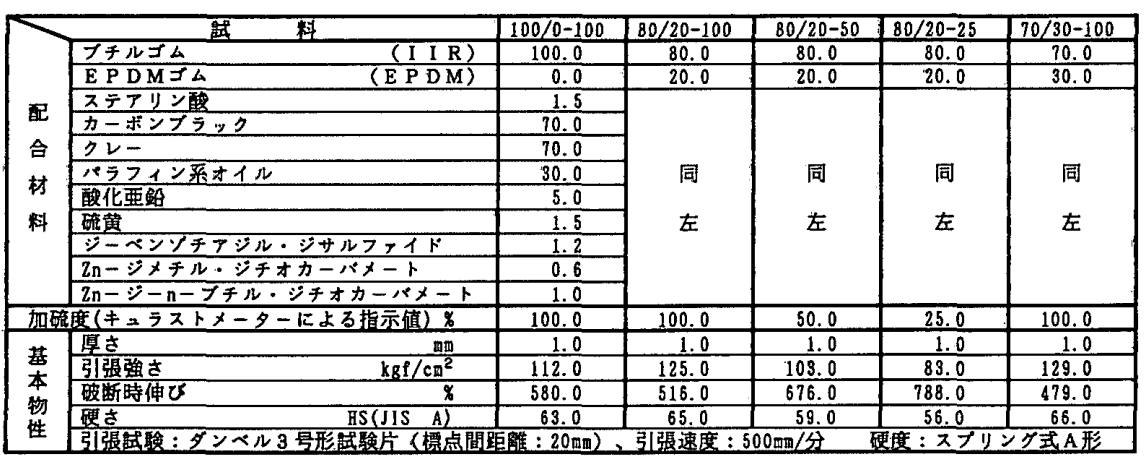

$-10-$
られるブチル/EPDM ゴムシートであり，ブチルゴム と EPDM の配合比を変えて, オゾンに対する性能に差 を設けた試料（IIR/EPDM の配合比で 100\%，80/20， 70/30 と略記）とした。なお，その加硫度は原則として キュラストメータ指示值で $100 \%$ としたが, 力学的負 荷を受けている状態での材料のオゾン劣化には，力学的 性質も強く関与するため, 試料 80/20についてはモデュ ラスを低下させた，加硫度がキュラストメ一夕指示值で $25,50 \%$ の試料も追加した。試料の配合比, 加硫度お よびその基本物性を表一1に示す。なお, 試験片は久陥 発生の観察面積が大きい，図一1に示す JIS K 6301 に 規定されるダンベル状 1 号形試験片を使用儿た。試験片 数は各条件 2 個ずつとした。

\section{3 試験方法}

既報闬で，オソン劣化には力学的負荷条件が重要であ り，これを前提として耐オゾン性を評価する必要がある ことを指摘したが，ここでの大気暴露試験でもそれらの 点を考虑し, 定ひずみ負荷と定応力負荷について検討し た。その条件は，前者では伸長率 $50,100,200 \%$ の 3 段階, 後者については応力 $5,10,20 \mathrm{kgf} / \mathrm{cm}^{2}$ の 3 段階 とした。

試験状況を写真一2 に示す。定ひずみ試験では固定金 具に試験片を取り付け，所定のひずみになるまで試験片 を伸長した後固定し, 伸長状態を保った。定応力試験で は試験片の上端部を固定し，下段部に所定の応力値にな るようあらかじめ重量を测定したおもりを懸垂させ，そ のまま放置した。試験片の観察は 1 日に 1 回行い，10 倍のルーペを用い, 亀裂発生の有無, 破断について調べ た。

\section{4 暴露場所および期間}

大気暴露試験は, 横浜市緑区, 東京工業大学長津田キャ ンパス内の 9 階建て建物の塔屋屋上であり，1989 年 7 月 23 日から 1992 年 7 月 22 日までの 3 年間行った。 
3. 暴露期間中の環境条件および 試験結果

3.1 オゾン濃度と試験片温度 オゾン濃度と試験片温度の1日 の変化の一例を図一 2 に示す。左 側の図は夏季の晴天日の例である が，オゾン濃度は細かく変動しな がら昼にかけて上昇し，夕方から 夜間にかけて減少する。. 試験片温 度も，日の出とともに上昇を開始 し, 昼にピークを持ち夕方に低下 する。一方, 晨天日の場合はオゾ ン濃度, 試験片温度とも上昇せず, 終日低い值にとどまっている。も ちろん，これらはその日の環境状 態によって異なる挙動を示すが, これを1日ごとの最大値と最小値 について整理し，図一-3に暴露期 間 3 年間のオゾン濃度, 図一 4 に 材料温度を示す。オゾン濃度の最 大值については, 季節の差が明瞭 にみられており，全体的には夏季 に高濃度の日が頻度多く観測さ れ，冬季には低濃度の日が多く観 測される。最小值についてはかな り低い值であり，また，年間を通 してそれほど変わらない。試験片 温度については, 最大值, 最小値 とも季節の差が顕著であり, 全体 的に夏季には高温側に，冬季には 低温側に移動する。
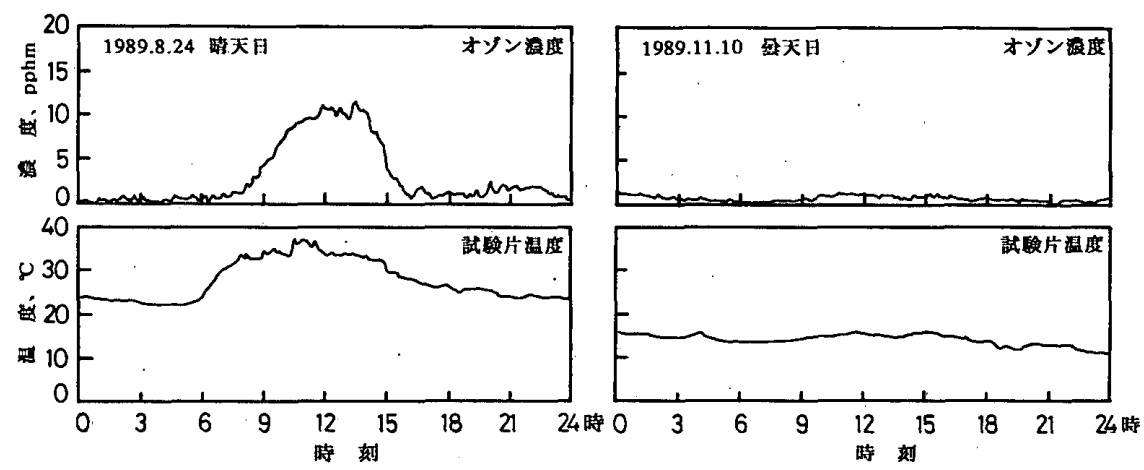

図一2 横浜市緑区長津田における1日のオゾン濃度, 試験片温度の観測值

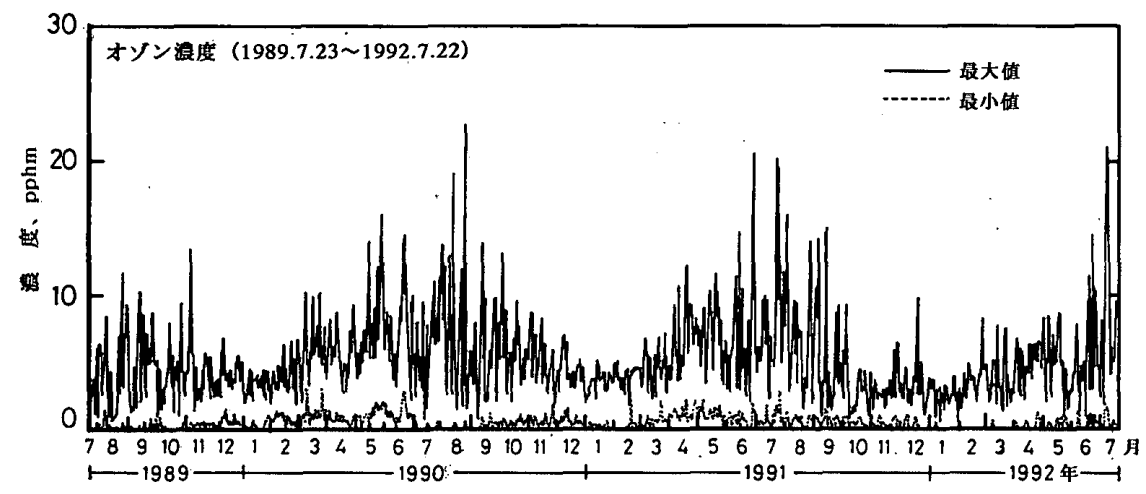

図一3 横浜市緑区長津田における 3 年間のオゾン濃度の観測值

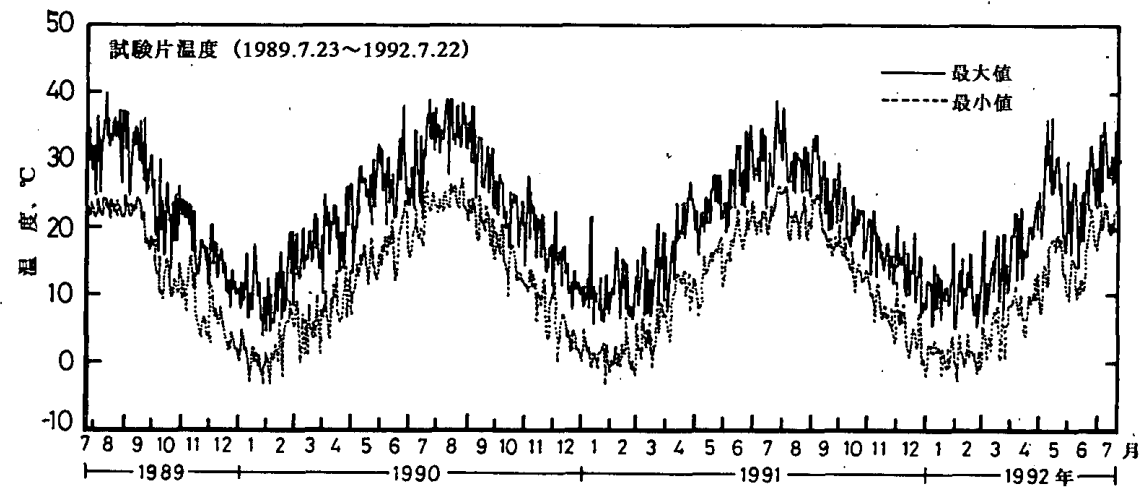

図一4 横浜市緑区長津田における 3 年間の試験片温度の観測値

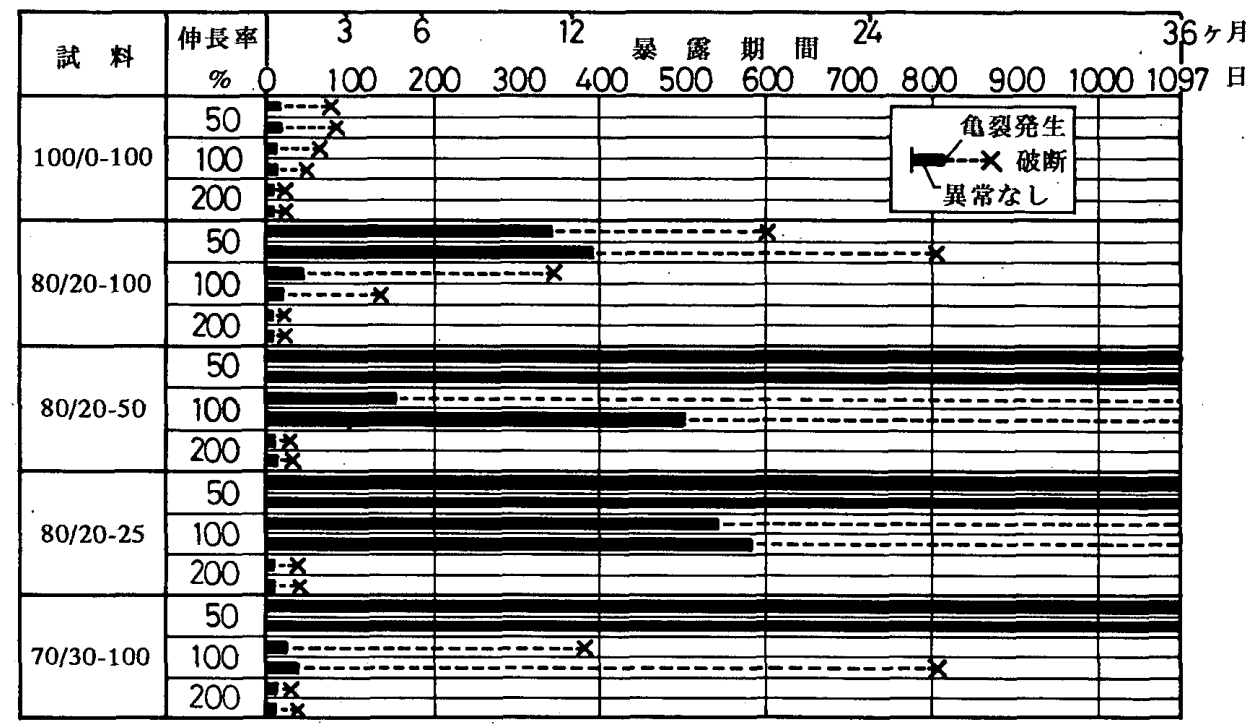

図一5 定ひずみ負荷下での暴露試験結果 


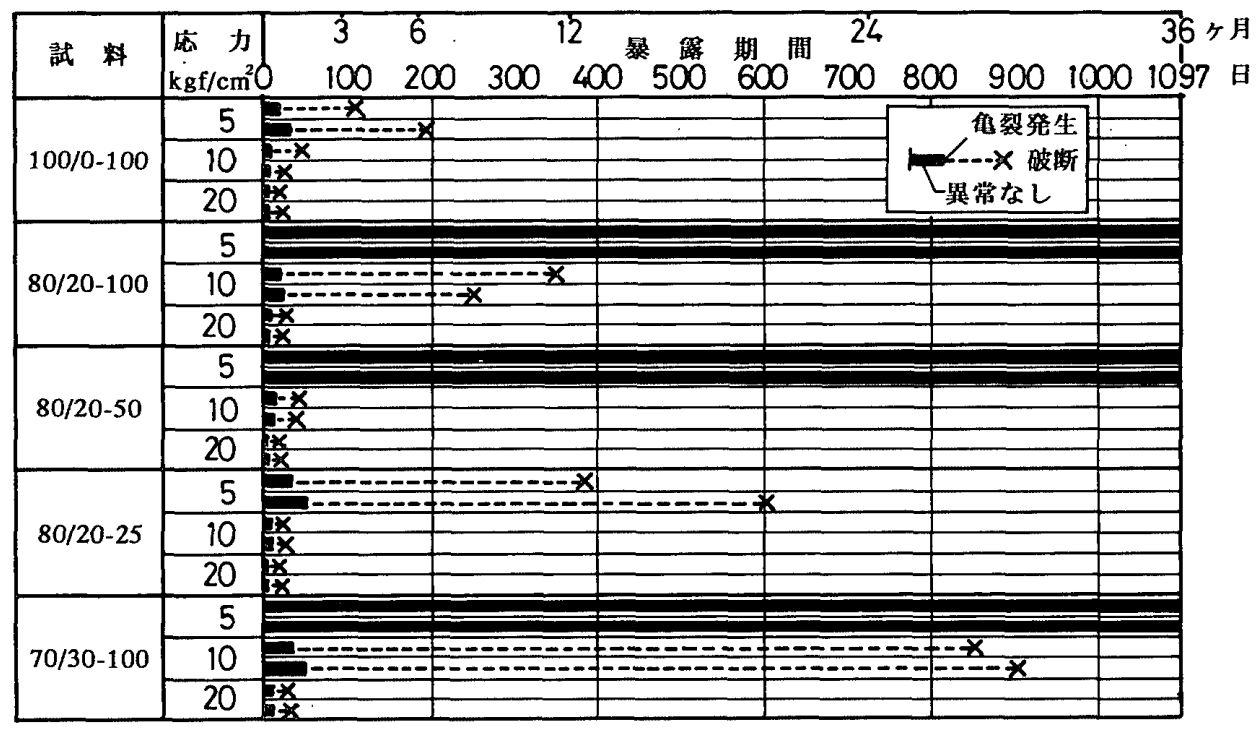

図-6 定応力負荷下での暴露試験結果

\section{2 暴露試験結果}

図一 5 に各試料ごとの定ひずみ負荷下での，図一 6 に 定応力負荷下での, 鱼裂発生までの日数と破断までの日 数を示す。定ひずみ負荷試験では，EPDM ゴムの配合 比が少ない試料では高伸長率の場合, 1 週間未満で亀裂 が発生するものもあるが，全般的に EPDM ゴムの配合 比が増加するに従い, 亀裂発生, 破断までの日数が長く なる。また，伸長率の影響も明瞭であり，当然ながら伸 張率が大きくなるに従って欠陥発生までの日数が短くな る。

定応力負荷試験についても同様の傾向が見られ， EPDM ゴムの配合比が大きい試料ほど久陷発生までの 日数が長くなる。さらに，負荷応力の大きさの影響も顕 著であり, 応力が高くなるに従って欠陷発生までの日数 は減少する。

\section{4. 欠陷発生までの時間の予測}

ここでは，暴露期間中観測されたオゾン濃度と試験片 温度を利用して, 各試料の欠陥発生までの時間の予測を 試みる。

\section{1 欠陷発生時間の計算方法}

基本的には前報”で示したオゾン濃度，温度が同時に 変動する環境下でのオゾン劣化予測の考え方に従う。こ こでその方法を再び簡単に記す。

一定オゾン濃度, 温度環境下でのオゾン劣化による欠 陥発生までの時間は,

$$
t=10^{(C / T+D)} / X^{A}
$$

$$
\text { ここに } t \text { : 欠陷発生時間, 時間 }(h)
$$$$
X: \text { オンン濃度, pphm }
$$

$A, C, D:$ 材料係数

$T:$ 絶対温度, $K$

と書き表すことができる。この式を書き改めると，

$$
\frac{X^{A}}{10^{(C / T+D)}} \times t=1
$$

となる。この式はオゾン濃度 $X$, 温度 $T$ の状態が $t$ 時 間続くと欠陥が発生することを表すものである。任意に オゾン濃度, 温度が変動する環境下においても, オン゙ン による劣化の加算性が成立することを仮定し，左辺は一 定オゾン濃度, 温度状態が短い時間間隔で変化している と考えると, 時間区分 $t_{n}$ までの総和

$$
\sum_{i=1}^{n} \frac{X_{i}^{A}}{10^{\left(C / T_{i}+D\right)}} \times t_{i}
$$

がちょうど 1 になった時，欠陥が発生することになる。 この時点までの経過時間 $\sum_{i=1}^{n} t_{i}$ が久陥発生までの時間之 なる。

実際の計算においては，各試料についてすでに前報” で得ている, 表一 2 , 表一 3 に示すオゾン濃度, 温度の 同時作用時の欠宿発生までの時間を表す数式を用い，10 分間隔ごとに実側されたオゾン濃度と試験片温度を遂次 （3）式に代入し，その総和が 1 となるまでの時間，す なわち久陷発生までの時間を求めた。

\section{2 計算結果と暴露試験結果との比較}

図一7に定ひずみ負荷下での亀裂発生，破断までの計 算による予測日数と暴露試験結果を，図一8に定応力負 荷下での予测日数と暴露試験結果を示す。各試料, 2 個 の試験片の結果で示されており，闭者は必ずしも同じ時 に欠陥が発生している訳ではないが，伸長率の増加とと もに亀裂発生，破断までの時間は堿少している。計算に よる欠陥発生予測日数も同じ傾向を示しており，一部暴 露試験結果亡差のあるものもあるが，おおむむ両者はよ い整合性を見せている。

また，定応力負荷の場合についてであるが，応力のレ ベルが上昇するに従い, 暴露試験では欠陷発生までの日 数は短くなり，計算による予测日数も同じ傾向を示し， 
表一2 定ひずみ負荷下での久陥発生までの時間を表す数式

\begin{tabular}{|c|c|c|c|}
\hline 武 & 伸張率 & 它裂発生 & 破断 \\
\hline \multirow{3}{*}{$100 / 0-100$} & $50 \%$ & $t=\frac{10^{\left(2.85 * 10^{3} / \mathrm{T}-5.95\right)}}{x^{1.42}}$ & $t=\frac{10^{\left(1.07 * 10^{3} / \tau+0.11\right)}}{x^{1.11}}$ \\
\hline & $100 \%$ & $t=\frac{10^{\left(3.22 * 10^{3} / \mathrm{T}-7.54\right)}}{1.42}$ & $t=\frac{10^{\left(0.96 * 10^{3} /(T+0.18)\right.}}{1.11}$ \\
\hline & $200 \%$ & $t=\frac{10^{\left(2.83 * 10^{3} / T-6.63\right)}}{x^{1.42}}$ & $t=\frac{10^{\left(1.56 * 10^{3} / \mathrm{T}-2.08\right)}}{x^{1.11}}$ \\
\hline \multirow{3}{*}{$80 / 20-100$} & $50 x$ & $t=\frac{10^{\left(3.58+10^{3} / T-7.71\right)}}{x^{1.25}}$ & $t=\frac{10^{\left(2.57 * 10^{3} / \mathrm{T}-4.11\right)}}{1.30}$ \\
\hline & $100 \%$ & $t=\frac{10^{\left(3.73 * 10^{3} / \mathrm{T}-9.26\right)}}{1.25}$ & $t=\frac{10^{\left(2.57 * 10^{3} / \mathrm{T}-4.61\right)}}{1.30}$ \\
\hline & $200 \%$ & $\mathrm{t}=\frac{10^{\left(3.65 * 10^{3} / \tau-9.87\right)}}{x^{1.25}}$ & $\mathrm{t}=\frac{10^{\left(2.75 * 10^{3} / \tau-5.67\right)}}{x^{1.30}}$ \\
\hline \multirow{3}{*}{$80 / 20-50$} & $50 x$ & & 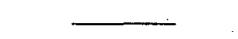 \\
\hline & $100 \%$ & $\mathrm{t}=\frac{10^{\left(3.03 * 10^{3} / \mathrm{T}-6.80\right)}}{x^{1.03}}$ & $t=\frac{10^{\left(2.79 * 10^{3} / \mathrm{T}-5.39\right)}}{x^{1.05}}$ \\
\hline & 2008 & $\mathrm{t}=\frac{10^{\left(4.03 * 10^{3} / \mathrm{T}-11.2\right)}}{x^{1.03}}$ & $t=\frac{10^{\left(2.79 * 10^{3} / \mathrm{T}-6.02\right)}}{x^{1.05}}$ \\
\hline \multirow{3}{*}{$80 / 20-25$} & $50 \%$ & & \\
\hline & $100 \%$ & $t=\frac{10^{\left(4.83 * 10^{3} / \mathrm{T}-11.98\right)}}{x^{1.12}}$ & $t=\frac{10^{\left(2.18 * 10^{3} / \mathrm{T}-3.09\right)}}{x^{1.00}}$ \\
\hline & 200x, & $\mathrm{t}=\frac{10^{\left\langle 2.94 * 10^{3} / \mathrm{T}-7.50\right\rangle}}{x^{1.12}}$ & $t=\frac{10^{\left(2.18 * 10^{3} / \tau-4.07\right)}}{1.00}$ \\
\hline \multirow{3}{*}{$70 / 30-100$} & $50 \%$ & $\mathrm{t}=\frac{10^{\left\{2.95 * 10^{3} / \tau-5.47\right\}}}{x^{0.95}}$ & $t=\frac{10^{\left(2.48 * 10^{3} / \tau-3.54\right)}}{x^{1.02}}$ \\
\hline & $100 \%$ & $t=\frac{10^{\left(2.95 * 10^{3} / T-6.43\right)}}{x^{0.95}}$ & $t=\frac{10^{\left(2.48 * 10^{3} / \tau-4.31\right)}}{x^{1.02}}$ \\
\hline & $200 \%$ & $\mathrm{t}=\frac{10^{\left(4.39 * 10^{3} / \mathrm{T}-12.17\right)}}{x^{0.95}}$ & $t=\frac{10^{\left(2.44410^{3} / T-5.07\right)}}{x^{1.02}}$ \\
\hline
\end{tabular}

表一3 定応力負荷下での久宿発生までの時間を表す数式.

\begin{tabular}{|c|c|c|c|}
\hline 武 料 & 底 力 & 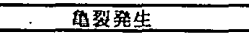 & 破 断 \\
\hline \multirow{6}{*}{$100 / 0-100$} & \multirow{2}{*}{$5 \mathrm{kgf} / \mathrm{cm}^{2}$} & $t=10^{\left(2.85 * 10^{3} / T-6.18\right)}$ & \multirow{2}{*}{$t=\frac{10^{\left(2.15 * 10^{3} / T-3.55\right)}}{x^{0.85}}$} \\
\hline & & $x^{0.81}$ & \\
\hline & \multirow{2}{*}{$10 \mathrm{kgf} / \mathrm{cm}^{2}$} & $10^{\left(3.98 * 10^{3} / \mathrm{T}-10.82\right)}$ & \multirow{2}{*}{$t=\frac{10^{\left(2.01 * 10^{3} / T-3.66\right)}}{x^{0.85}}$} \\
\hline & & $t=\frac{x^{0.81}}{.}$ & \\
\hline & \multirow{2}{*}{$20 \mathrm{kgf} / \mathrm{cm}^{2}$} & $10^{\left(2.83 * 10^{3} / \mathrm{T}-7.69\right)}$ & \multirow{2}{*}{$t=\frac{10^{\left(2.16 * 10^{3} / T-4.47\right)}}{x^{0.85}}$} \\
\hline & & $t=\frac{x^{0.81}}{10}$ & \\
\hline \multirow{5}{*}{$80 / 20-100$} & $5 \mathrm{kgf} / \mathrm{cm}^{2}$ & & \\
\hline & \multirow{2}{*}{$10 \mathrm{kgf} / \mathrm{cm}^{2}$} & $10^{\left(3.51 * 10^{3} / \mathrm{T}-7.98\right)}$ & \multirow{2}{*}{$t=\frac{10^{\left(2.38 * 10^{3} / T-3.91\right)}}{x^{1.00}}$} \\
\hline & & $x^{1.14}$ & \\
\hline & \multirow{2}{*}{$20 \mathrm{kgf} / \mathrm{cm}^{2}$} & $10^{\left(3.51 * 10^{3} / T-8.94\right)}$ & \multirow{2}{*}{$t=\frac{10^{\left(1.88 * 10^{3} / T-3.24\right)}}{x^{1.00}}$} \\
\hline & & $x^{1.14}$ & \\
\hline \multirow{5}{*}{$80 / 20-50$} & \multicolumn{2}{|l|}{$5 \mathrm{kBf} / \mathrm{CE}^{2}$} & \\
\hline & \multirow{2}{*}{$10 \mathrm{kgf} / \mathrm{cm}^{2}$} & $10^{\left(4.04 * 10^{3} / \mathrm{T}-10.92\right)}$ & \multirow{2}{*}{$t=\frac{10^{\left(2.67 * 10^{3} / T-5.85\right)}}{x^{1.05}}$} \\
\hline & & $x^{0.81}$ & \\
\hline & \multirow[b]{2}{*}{$20 \mathrm{kgf} / \mathrm{CD}^{2}$} & $10^{\left(4.04 * 10^{3} / \mathrm{T}-11.40\right)}$ & \multirow{2}{*}{$t=\frac{10^{\left(2.67 * 10^{3} / T-6.51\right)}}{x^{0.80}}$} \\
\hline & & $t=-x^{0.81}$ & \\
\hline \multirow{6}{*}{$80 / 20-25$} & \multirow{2}{*}{$5 \mathrm{kgf} / \mathrm{cm}^{2}$} & $t=10^{\left(3.30 * 10^{3} / \Upsilon-7.13\right)}$ & \multirow{2}{*}{$t=\frac{10^{\left(2.10 * 10^{3} / T-2.59\right)}}{x^{0.92}}$} \\
\hline & & $x^{1.06}$ & \\
\hline & \multirow[b]{2}{*}{$10 \mathrm{kgf} / \mathrm{cm}^{2}$} & $10^{\left(3.34 * 10^{3} / \mathrm{T}-8.71\right)}$ & \multirow{2}{*}{$t=\frac{10^{\left(2.18 * 10^{3} / \mathrm{T}-4.47\right)}}{x^{0.92}}$} \\
\hline & & $t=-\frac{x^{1.06}}{1.06}$ & \\
\hline & \multirow{2}{*}{$20 \mathrm{kgf} / \mathrm{cm}^{2}$} & $10^{\left(3.49 * 10^{3} / \mathrm{T}-9.57\right)}$ & \multirow{2}{*}{$t=\frac{10^{\left(3.17+10^{3} / T-8.10\right)}}{x^{0.92}}$} \\
\hline & & $t=\frac{x^{1.06}}{x^{1.0}}$ & \\
\hline \multirow{5}{*}{$70 / 30-100$} & \multicolumn{2}{|l|}{$5 \mathrm{kgf} / \mathrm{cm}^{2}$} & 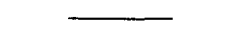 \\
\hline & \multirow{2}{*}{$10 \mathrm{kgf} / \mathrm{cm}^{2}$} & $10^{\left(4.11 * 10^{3} / T-9.33\right)}$ & \multirow{2}{*}{$t=\frac{10^{\left(2.38 * 10^{3} / T-3.52\right)}}{x^{1.00}}$} \\
\hline & & $x^{0.95}$ & \\
\hline & \multirow{2}{*}{$20 \mathrm{kgf} / \mathrm{cm}^{2}$} & $10^{\left(4.11 * 10^{3} / T-10.93\right)}$ & \multirow{2}{*}{$t=\frac{10^{\left(2.38 * 10^{3} / T-4.61\right)}}{x^{1.00}}$} \\
\hline & & $x^{0.95}$ & \\
\hline
\end{tabular}

この場合も両者は比較的よい整 合性を示している。

\section{5. 屋外暴露試験とオゾン試験 との関係}

\section{1 相当環境オゾン濃度}

屋外での変動するオゾン濃度 がオゾン劣化に与える影響の理 解を容易にするため，変動する オゾン環境での劣化と等価とな る一定のオゾン濃度として定義 される，相当環境オゾン濃度を 試算する。

前報1でも述べたように，屋 外環境のようにオン゙ン濃度と温

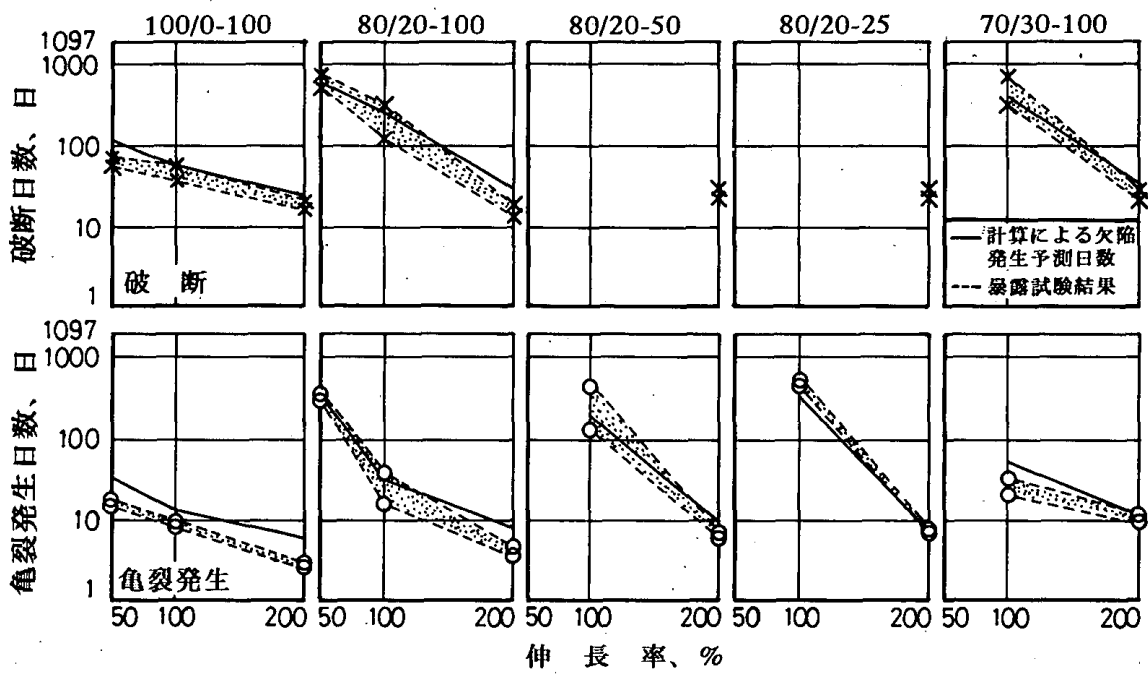

図一7定ひずみ負荷下での計算による久宿発生予測日数と暴簬 試験結果との比較 度が同時に変動する場合には，どちらか一方を固定しな ければ他方を決めることができず，ここでは試験片温度 をその平均值で表すこととし，相当環境オゾン濃度を求 めた。また欠陥としては試験片破断までの日数とした。 これは亀裂発生の観察に比べて主観が入りにくく，デー タとしての信頼性が高いためである。

相当環境オゾン濃度 $(\dot{X}$ eqv $)$ の計算は，既報")で示し た次式によった。

$$
X_{e q v}^{A}=\frac{10^{(C / \text { Tave }+D)}}{\sum_{i=1}^{n} t_{i}}
$$

また，温度は試験片の暴露期間 3 年間の平均值 $15.7^{\circ} \mathrm{C}$ を代入した。得られた結果を表一 4 に示す。暴露した試 験片が各条件 2 個ずつであり，破断までの日数が必ずし も同一でなかったため, 相当環境オゾン濃度は 2 つ得ら れ，両計算結果の範囲で示した。もちろん，試料によっ 
てオゾンに対する影響の程度が 異なるため,その值には差があ るが，おおむね数 pphm 程度の 範囲であった。ここで注意すべ きは，相当環境オゾン濃度が材 料により，または負荷の程度に よって異なる点である。このこ とはオゾンの影響が単純な平均 値, 例えば平均オゾン濃度と いった量では評価が不可能であ り, 相当環境オゾン濃度での評 価の必要性を意味するものであ る。

5.2 屋外暴露と等価となるオ ゾン試験の条件

ここでさらに，亀裂発生まで の時間と等価となるオゾン試験 条件について考察する。ほとん どのオゾン試験では試験時間の 短縮化を図るため, 高濃度, 高 温度で試験がなされており，そ の関係を知ることは試験条件の 持つ意味を明らかにする点で重 要だからである。

比較するオゾン試験条件とし ては，日本工業規格中のオゾン 試験条件 ${ }^{12)-14)}$ あるいは ISO 規 格 ${ }^{15)}$ 中のオゾン試験条件の中から頻繁に使用される 3 条 件, 試験温度 $40^{\circ} \mathrm{C}$ でオゾン濃度 $25,50,75 \mathrm{pphm}$ を選 んだ。各条件下で屋外暴露での破断までの時間と等価と なるオゾン試験時間を計算し, 表一 5 と表一 6 に示す。 当然，等価となる時間は試料により，あるいは負荷条件

表一5 計算により求めた屋外での破断までの時間と等価となる オソン試験時間（定ひずみ負荷について）

\begin{tabular}{|c|c|c|c|c|}
\hline \multirow{2}{*}{ 試 料 } & \multirow{2}{*}{ 伸長率 } & \multicolumn{3}{|c|}{ オソン試験の条件 } \\
\hline & & $\begin{array}{l}25 \mathrm{pphm} \\
40^{\circ} \mathrm{C}\end{array}$ & $\begin{array}{l}50 \mathrm{pph} \\
40^{\circ} \mathrm{C}\end{array}$ & $\begin{array}{l}75 \mathrm{pphg} \\
40^{\circ} \mathrm{C}\end{array}$ \\
\hline $100 / 0-100$ & $\begin{array}{l}50 \% \\
100 \\
200\end{array}$ & $\begin{array}{l}94.4 \text { 時間 } \\
49.4 \\
22.4\end{array}$ & $\begin{array}{l}43.8 \text { 時間 } \\
22.9 \\
10.4\end{array}$ & $\begin{array}{l}27.9 \text { 時間 } \\
14.6 \\
6.6\end{array}$ \\
\hline $80 / 20-100$ & $\begin{array}{l}50 \% \\
100 \\
200\end{array}$ & $\begin{array}{c}190.4 \text { 時間 } \\
60.2 \\
5.2\end{array}$ & $\begin{array}{l}77.3 \text { 時間 } \\
24.4 \\
2.1\end{array}$ & $\begin{array}{c}45.6 \text { 時閻 } \\
14.4 \\
1.3\end{array}$ \\
\hline $80 / 20-50$ & $\begin{array}{l}50 \% \\
100 \\
200\end{array}$ & 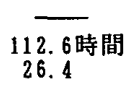 & $\begin{array}{l}\overline{54.4 \text { 時間 }} \\
12.8\end{array}$ & $\begin{array}{l}35.5 \text { 時間 } \\
8.3\end{array}$ \\
\hline $80 / 20-25$ & $\begin{array}{l}50 \% \\
100 \\
200\end{array}$ & $\begin{array}{l}202.2 \text { 時間 } \\
21.2\end{array}$ & $\begin{array}{l}93.0 \text { 時間 } \\
9.7\end{array}$ & $\begin{array}{l}5 \overline{5.1 \text { 時間 }} \\
6.2\end{array}$ \\
\hline $70 / 30-100$ & $\begin{array}{l}50 \% \\
100 \\
200\end{array}$ & $\begin{array}{c}898.7 \text { 時間 } \\
152.6 \\
19.8\end{array}$ & $\begin{array}{c}\text { 443. } 2 \text { 時間 } \\
75.3 \\
9.7\end{array}$ & $\begin{array}{c}293.1 \text { 時間 } \\
49.8 \\
6.4\end{array}$ \\
\hline
\end{tabular}

一：数式が得られていないため求められなかった。
により異なるが，屋外暴露とオゾン試験の関係について 考察する。定ひずみ負荷の場合，図一5の定ひずみ負荷 下での暴露試験で，暴露期間 3 年以内に破断した試料の 計算上等価となる試験時間は，オゾン濃度 $25 \mathrm{pphm} の$ 試験条件下でも 200 時間以内であった。定応力負荷の場

表一6 計算により求めた屋外での破断までの時間と等価となる オゾン試験時間（定応力負荷について）

\begin{tabular}{|c|c|c|c|c|}
\hline \multirow{2}{*}{ 試 料 } & \multirow{2}{*}{ 応 力 } & \multicolumn{3}{|c|}{ オソン試験の条件 } \\
\hline & & $\begin{array}{l}25 \mathrm{pphm} \\
40^{\circ} \mathrm{C}\end{array}$ & $\begin{array}{l}50 \mathrm{pphm} \\
40^{\circ} \mathrm{C}\end{array}$ & $\begin{array}{l}75 \text { ppho } \\
40^{\circ} \mathrm{C}\end{array}$ \\
\hline $100 / 0-100$ & $\begin{array}{l}5 \mathrm{kgf} / \mathrm{cm}^{2} \\
10 \\
20\end{array}$ & $\begin{array}{l}134.1 \text { 時間 } \\
37.2 \\
17.4\end{array}$ & $\begin{array}{l}74.4 \text { 時間 } \\
20.6 \\
9.6\end{array}$ & $\begin{array}{l}52.7 \text { 時間 } \\
14.6 \\
6.8\end{array}$ \\
\hline $80 / 20-100$ & $\begin{array}{l}5 \mathrm{kgf} / \mathrm{cm}^{2} \\
10 \\
20\end{array}$ & $\begin{array}{l}196.0 \text { 時間 } \\
23.2\end{array}$ & $\begin{array}{l}\overline{98.0 \text { 時間 }} \\
11.6\end{array}$ & $\begin{array}{l}\text { 65.3時間 } \\
7.7\end{array}$ \\
\hline $80 / 20-50$ & $\begin{array}{l}5 \mathrm{kgf} / \mathrm{cm}^{2} \\
10 \\
20\end{array}$ & $\begin{array}{l}3 \overline{3.1} \text { 時間 } \\
7.9\end{array}$ & $\begin{array}{l}20.8 \text { 時間 } \\
4.5\end{array}$ & $\begin{array}{l}15.0 \text { 時間 } \\
3.3\end{array}$ \\
\hline $80 / 20-25$ & $\begin{array}{l}5 \mathrm{kgf} / \mathrm{cm}^{2} \\
10 \\
20\end{array}$ & $\begin{array}{c}676.0 \text { 時間 } \\
16.0 \\
5.5\end{array}$ & $\begin{array}{l}\text { 357. } 3 \text { 時間 } \\
8.5 \\
2.9\end{array}$ & $\begin{array}{c}246.0 \text { 時間 } \\
5.8 \\
2.0\end{array}$ \\
\hline $70 / 30-100$ & $\begin{array}{l}5 \mathrm{kgf} / \mathrm{cm}^{2} \\
10 \\
20\end{array}$ & $\begin{array}{l}48 \overline{1.1 \text { 時間 }} \\
39.1\end{array}$ & $\begin{array}{l}240 . \overline{6 \text { 時間 }} \\
19.6\end{array}$ & $\begin{array}{l}16 \overline{0.4 \text { 時間 }} \\
13.0\end{array}$ \\
\hline
\end{tabular}

一：数式が得られていないため求められなかった。 
合も，図一6の定応力負荷下での暴露試験結果と比較し ながら考察すると, 暴露試験で 3 年以内に破断した試料 の計算上等価となる試験時間は, オゾン濃度 $25 \mathrm{pphm}$ の試験条件でも 700 時間以内であった。したがって, 高 濃度で試験を行う場合, 特に建築用ゴム系材料のオゾン 試験で多用される $75 \mathrm{pphm}$ のオゾン濃度の試験を例に 取ると, 表一 5 , 表一 6 に示す計算時間より判断して, 300 時間程度試験を行えば, 暴露期間 3 年以内で破断す るかどうか，という予測には十分であるといえる。しか し，それを超える範囲については基本的には本研究で示 した考え方で推定が可能と考えられるが，現段階では確 認していない。

\section{6. 結 論}

建築用ゴム系材料のオゾン劣化を予测する手法により 屋外暴露での久陥発生までの時間を計算し，その適用性 を検討した本研究で得られた結論は以下のとおりであ る。

（1）屋外暴露期間中測定したオゾン濃度と試験片温度 を，陷発生時間を表す数式に代入して得た，欠陥発生 予測日数は暴露試験結果とほぼ近く，本報までで示した 考え方により，オン゙ンによる劣化をほぼ定量的に取り扱 うことが可能である。

（2）さらに大気暴露試験とオゾン試験条件との関係を 定量的に結び付けることを可能とし，試験条件の位置付 けを明らかにした。

なお，ここまで行った議論はすべて負荷状態が静的状 態の現象についてである。これが絽返し負荷を受ける場 合には，陷発生までの時間が短縮化される。したがっ て, 動的状態下での劣化は本研究の範囲外であり, 今後 の課題である。

\section{参考女献}

1）田中享二, 㷊 怲昌, 小池迪夫 : オゾン濃度, 温度が同 時に変動する環境下での建築用ゴム系材料のオゾン劣化 の評価：日本建築学会構造系論文報告集, 第 443 号, pp. 17 23, 1993 年 1 月

2) Antti Soininen, Anna-Liisa, Pehu-Lehtonon and Elli Auterinen : Atomospheric Ozone in Helsinki and Its Effects on Rubber; Rubber Chem. Tech. Vol. 36, No.2, pp. 516 530, 1963

3) A. J. Haagen-Smit, M. F. Brunelle and J. W. HaagenSmit: Ozone Cracking in the Los Angeles Area; Rubber Chem. Tech. Vol. 32, No. 4, pp.1134 1142, 1959

4) G.N. Vacca : Comparison of Acceleated and Natural Tests for Ozone Resistance of Elastomers; Rubber Chem. Tech Vol.32, No.4, pp. 1080 1087, 1959

5）須賀 荡：ゴムの屋外ばく露試験と促進試験について; 日 本ゴム協会誌, 42[5], pp. 90 102，1969

6）高木暢太郎, 白石章二, 増田 剛：合成ゴムシート防水 材屋外暴露試験; 日本建築学会学術講演梗概集 (構造系), pp. $263 \sim 264,1968$

7）藤木俊昭：シート防水における保証品位妥当性の検討； 品質管理 21 [11]，pp. 31－33，1970

8）加藤正守, 吉池祐一：合成高分子防水材の耐オゾン性に 関する屋外暴露と促進劣化の関連性; 日本建築学会大会 学術講演梗概集, pp. 49 50, 1974

9）日本ゴム協会編：ゴム試験法; pp. 463 488, 昭和 38 年

10) 田中享二, 宋 炳昌, 小池迪夫：建築用ゴム系材料の才 ゾン試験における力学的負荷条件の考察; 日本建築学会 構造系論文報告集, 第 417 号, pp. 1 8, 1990 年 11 月

11）田中毫二, 宋 炳昌, 小池迪夫：建築用ゴム系材料の変 動するオゾン濃度下での劣化の評価; 日本建築学会構造系 論文報告集, 第 428 号, pp. 47 53,1990 年 5 月

12) JIS K 6301 ：加硫ゴム物理試験方法, 1975

13） JIS A 6008：合成高分子ルーフィング, 1986

14）JIS A 5757 ：建築用シーリング材の用途別性能, 1975

15) ISO $1431 / 1:$ Rubber, Vulcanized-Resistance to Ozone Cracking, 1980-Part 1; Static Strain Test

(1992 年 12 月 9 日原稿受理, 1993 年 4 月 21 日採用決定) 